\title{
Cultural values and sustainable rural development: A brief introduction
}

DOI: $10.3986 / A G S 53401$

UDC: $911.373: 338.483 .12(4)$

COBISS: 1.03

David Bole, Ph. D.

Anton Melik Geographical Institute

Research Center of the Slovenian Academy of Sciences and Arts

Gosposka ulica 13, SI - 1000 Ljubljana, Slovenia

E-mail: david.bole@zrc-sazu.si

Primož Pipan, Ph. D.

Anton Melik Geographical Institute

Research Center of the Slovenian Academy of Sciences and Arts

Gosposka ulica 13, SI - 1000 Ljubljana, Slovenia

E-mail: primoz.pipan@zrc-sazu.si

Blaž Komac, Ph. D.

Anton Melik Geographical Institute

Research Center of the Slovenian Academy of Sciences and Arts Gosposka ulica 13, SI - 1000 Ljubljana, Slovenia

E-mail: blaz.komac@zrc-sazu.si 


\section{Introduction}

Rural development has been based on more than farming, forestry, and other production functions for some time. Globalization and the societal shift from production to consumption also have a fundamental impact on the countryside, where we are discovering continually new patterns of social and economic organization. Local stakeholders primarily see new development opportunities in tourism and accompanying activities. A study that included over 300 small rural municipalities within the Alpine Convention area most often mentioned tourism activities as the greatest development opportunity (Bole and Nared 2009). Tourism in the countryside has become a »creative « solution for many problems that the countryside faces today (Horáková 2013, 23).

Promoting tourism can be explained as the commercialization and modernization of rural space. Together with depeasantization, these processes can be associated with globalization and the formation of the "global countryside (Araghi 1995). However, the global countryside is far from homogenous because it is marked by a mix of many cultural and natural features that create a unique and variegated countryside (for more on the global countryside, see Woods 2007). Because of diverse farming practices, lifestyles, and other cultural characteristics (e.g., food preparation), the countryside is becoming attractive to visitors, who are not only seeking natural values, but also wish to experience local culture (Butler and Hall 1998). Local culture is part of countryside capital, which according to some definitions also includes natural capital, architectural capital, and social capital (Page and Connell 2006). The characteristic local culture of a particular area is a development potential that is further emphasized by location and specific content, due to which local culture is most often connected with the natural, social, and historical endowments of a space and can represent a competitive advantage over other areas. From this perspective, culture (in the broadest sense of the word) and also cultural heritage can be defined with regard to its economic, sociological, ecological, and creative development potential, or its value can also be defined - from this stems the definition of the concept of »cultural value, « which is intended to emphasize the development potential of various forms of culture and the cultural heritage of a particular area (Šmid Hribar and Ledinek Lozej 2013). The integration of culture as an "alternative" community development source is a concept that has also proved useful in other studies (MacDonald and Jolliffe 2003). This special issue of Acta Geographica Slovenica presents eight articles that highlight the theoretical and methodological premises for studying culture and its role in the development of the countryside. At the same time, these are also interesting case studies of local culture.

\section{Articles}

Šmid Hribar and Ledinek Lozej (2013) discuss the role of identifying and managing cultural values in rural development in the case of the Idrija area in Slovenia. The authors determine that cultural and natural elements contribute to rural development. Identifying and evaluating development aspects and the interconnection of cultural values and local stakeholders are keys to managing cultural values. The authors define cultural values with development potential by studying relevant research and legislation. Field studies were carried out in the Idrija countryside, and an online questionnaire was used to evaluate development aspects.

Bigaran et al. (2013) discuss the use of medicinal and aromatic plants to promote local development in mountain areas in the case of the autonomous province of Trentino in Italy. The authors highlight the fact that, in order to achieve success, stakeholders' ability to use and enhance local resources is more important than the topic itself. In managing cultural values, successful good practice demands the active participation of local stakeholders, political will that affects economic and other initiatives, and finally enterprising marketing with promotion.

Nared et al. (2013) discuss the inclusion of development topics in a cultural heritage management plan based on a case study of mercury heritage in Idrija, Slovenia. The plan has been included on the UNESCO World Heritage List together with the Spanish town of Almadén. The authors present the key findings of participatory processes, aiming at forming a cultural heritage management plan that will ensure that heritage becomes an important driver of municipal development. The article highlights the need for comprehensive planning that includes all stakeholders, transcends divisions between sectors, and contributes to the harmonious and successful development of the area. 
Dragićević et al. (2013) discuss the evaluation of tourism attractiveness and museum management in the Sombor and Apatin areas in the province of Vojvodina, Serbia. The paper deals with the Silk Damask Museum in Bezdan, the Tobacco Museum in Telečka, and the Ethnological Exhibition in Kupusina. The authors used a model by Hilary du Cros to assess the tourism importance and management of cultural heritage based on the three museums. They argue that it is necessary to pay attention to museum conservation, carrying capacity, and visitor management.

Blešić et al. (2014) discuss cultural events as part of cultural tourism development based on case studies of the municipalities of Sombor and Apatin in the province of Vojvodina, Serbia. This multiethnic region is known for its folklore and food, which have given rise to numerous business and entertainment events. The paper contributes to a better understanding of residents' attitudes toward the social impacts of community festivals and how they can be used by the organizers to increase the social benefits generated by festivals and reduce their negative social impacts.

Stojanovićet al. (2014) discuss the principles of sustainable development of tourism in the Upper Danube Valley Special Nature Reserve (Specijalni rezervat prirode Gornje Podunavlje) in the province of Vojvodina and the impact of these principles on local communities. The authors analyze the importance of criteria for sustainable tourism, such as the importance of adopting certain principles of care, long-term planning, and management to integrate nature protection and tourism.

Loulanski and Loulanski (2014) discuss the socially-rooted process of heritization of the Bulgarian rose, indicating an expanding spectrum of modern purposes and uses, as well as a growing awareness to refer to and build upon its newly recognized multiple values. In addition to the historically strong record of various cultural uses of rose heritage in symbols, rituals, traditional folklore, arts, crafts, events, and festivals, today's growing synergy with tourism stands out as an approach that could enhance its fundamental values even further as an important catalyst of a sustainability-oriented socioeconomic development.

Klinar and Geršič (2014) discuss traditional house names as part of cultural heritage in Slovenia's Upper Carniola region. In the past, house names were an important factor in identifying houses, people, and other social structures, but modern social processes are decreasing their use. House names preserve the local dialect with its special features, and their motivational interpretation reflects historical, geographical, biological, and social conditions in the countryside.

The articles described here sum up the main finding that local culture is an appropriate resource for sustainable development for the countryside, but in and of itself is not sufficient for creating progress. As other authors have also determined (e.g., Bigaran et al. 2013; Šmid Hribar and Ledinek Lozej 2013), cultural values can only be an initial development resource that must be suitably evaluated and into which a great deal of knowledge, creativity, and innovation must be invested in order to use them to enrich society today. It is therefore unsurprising that development initiatives largely rely on local actors and their relations with one another, and that the process of creating a tourism product from a primary source (culture) with the aid of human and social capital must take place together with the local community or must proceed from it.

\section{Conclusion}

The creation of a tourism product that is based on local culture is a form of empowering the community, which can assume supervision and responsibility for its own development (Scheyvens 1999). Such a bottom-up approach in planning development with the help of cultural values is also important in order to prevent conflicts and achieve better long-term results (Zumaglini et al. 2008). Finally, it is also important of course that the fruits of countryside capital be enjoyed and experienced not only by visitors and tourists, but also by the local people (Horáková 2013, 25).

\section{Acknowledgements}

This article was prepared as part of the project SY_CULTour (Synergy of Culture and Tourism: Utilization of Cultural Potentials in Less-Favored Rural Areas) and was cofinanced by the Southeast Europe Transnational Cooperation Program, which is part of the European Territorial Cooperation objective of EU regional policy. 


\section{References}

Araghi, F. 1995: Global depeasantization, 1945-1990: The Sociological Quarterly 36. Hoboken. DOI: 10.1111/j.1533-8525.1995.tb00443.x

Bigaran, F., Mazzola, A., Stefani, A. 2013: Enhancing territorial capital for developing mountain areas: the example of trentino and its use of medicinal and aromatic plants. Acta Geographica Slovenica 53 (1). Ljubljana. DOI: 10.3986/AGS53403

Blešić, I., Pivac, T., Đorđević, J., Stamenković, I., Janićević, S. 2014: Cultural events as part of cultural tourism development. Case study: Sombor and Apatin (Serbia). Acta Geographica Slovenica 54 (1). In press. Ljubljana. DOI: 10.3986/AGS54406

Bole, D., Nared, J. 2009: The Future of Small Towns in Remote Mountainous Areas: The Alps. City Futures '09 proceedings. Internet: http://www.cityfutures2009.com/PDF/101_Bole_David.pdf (20.12.2012)

Bulter, R., Hall, M. 1998: Tourism and Recreation in Rural Areas. Hoboken.

Dragićević, V., Besermenji, S., Pivac, T., Ivkov-Džigurski, A., Košić, K. 2013. Evaluation of tourist attractiveness and museum management in Sombor and Apatin (Serbia). Acta Geographica Slovenica 53 (1). Ljubljana. DOI: 10.3986/AGS53405

Horáková, H. 2013: Whose countryside? Contested development in the new rural recreational localities in Czechia from the perspective of the countryside capital. European Countryside 1-2013. Berlin. DOI: 10.2478/euco-2013-0002

Klinar, K., Geršič M. 2014: Traditional house names as part of cultural heritage. Acta Geographica Slovenica 54 (1). In press. Ljubljana. DOI: 10.3986/AGS54409

Loulanski, V., Loulanski T. 2014: The heritization of Bulgarian rose. Acta Geographica Slovenica 54 (1). In press. Ljubljana. DOI: 10.3986/AGS54408

MacDonald, R., Jolliffe, L. 2003: Cultural rural tourism: Evidence from Canada. Annals of Tourism Research 30-2. Amsterdam. DOI: 10.1016/S0160-7383(02)00061-0

Nared, J., Erhartič, B., Razpotnik Visković, N. 2013: Including development topics in a cultural heritage management plan: Mercury heritage in Idrija. Acta Geographica Slovenica 53 (1). Ljubljana. DOI: 10.3986/AGS53404

Page, S., J., Connell, J. 2006: Tourism: A Modern Synthesis. London.

Scheyvens, R. 1999: Ecotourism and the empowerment of local communities. Tourism management 20. Amsterdam. DOI: 10.1016/S0261-5177(98)00069-7

Stojanović, V., Đorđević, J., Lazić, L., Stamenković, I., Dragićević, V. 2014: The principles of sustainable development of tourism in the special nature reserve "Gornje Podunavlje« and their impact on the local communities. Acta Geographica Slovenica 54 (1). In press. Ljubljana. DOI: 10.3986/AGS54407

Šmid Hribar, M., Ledinek Lozej, Š. 2013: The role of identifying and managing cultural values in rural development. Acta Geographica Slovenica 53 (1). Ljubljana. DOI: 10.3986/AGS53402

Woods: M. 2007: Engaging the global countryside: globalization, hybridity and the reconstitution of rural place. Progress in Human Geography 31-4. Thousand Oaks. DOI: 10.1177/0309132507079503

Zumaglini, M., Nared, J., Alfarè, L., Razpotnik, N., Urbanc, M. 2008: Participation Process in Regional Development: DIAMONT's Perspective. Arbaitshefte/Quaderni 52. Bolzano/Bozen. 